effective in fixing nitrogen. The old laboratory strains which have lost their virulence, that is, are unable to produce nodules when supplied to the plant, were found in most experiments to produce less growth-substance, as illustrated by the strain " 202 " in the table.

Bacteriology Department,

H. K. Chen.

Rothamsted Experimental Station, Harpenden. Sept. 7.

1 Thimann, K. V., Proc. Nat. Acad. Sci., 22, 511-514 (1936).

"Went, F. W., and Thimann, K. V., "Phytohormones", 54-55 (New York, 1937).

\section{Cyclical Changes in the Adrenal Glands of Spayed Rats}

IN an earlier note published in these columns ${ }^{1}$, it was reported that cyclical variations occur in the responsiveness of the uterus of spayed monkeys to constant œstrogenic stimulation. In view of several considerations, it was suggested in a later com. munication ${ }^{2}$ that variations in the size and function of the adrenal cortex, such as occur in normal rats in the cstrous cycle ${ }^{3}$, may be responsible for these cyclical variations in the uterine response. Later work $^{4}$ showed that cyclical uterine changes occur in spayed rats as well as in monkevs, and that the adrenal gland is probably concerned in their occurrence ${ }^{5}$.

We have now found that the adrenal gland does in fact continue to fluctuate in size in an approximately five day rhythm in spayed rats (Glaxo strain) that are injected daily with the same threshold dose of cestrone. The gland is larger at cestrus than in the dicstrous period, the observations being made on the basis of the difference between the ratios of adrenal weight in grams to body weight in kilograms. The difference between the two means in an equally divided experimental group of 38 rats of similar age and weight was significant, $P$ being less than $0 \cdot 01$.

\section{S. ZUCKERMAN. \\ G. Botrne (Beit Memorial Fellow). D. LEwES.}

Department of Human Anatomy, Oxford. Sept. 27.

1 Zuckerman, S., NATURE, 139, 628 (1937).

2 Long, C. N. H., and Zuckerman, S., NATURE, 139, 1106 (1937).

Anderson, D. H., and Kennedy, H. S., J. Physiol., "76, 247 (1932).

- Zuckerman, S., J. Physiol., 92, $12 P$ (1938).

' Zuckerman, S., J. Physiol., 92, 13 P (1938).

\section{Toxicity of Mercury Vapour to Insects}

A REFERENCE was made in a communication under this title by $\mathrm{H}$. C. Gough in Natrore of May 21, p. 922, to an old Indian custom of placing a small quantity of mercury in a container amongst stored pulses. It seems worth while to direct attention to an analogous belief amongst the Ahoms. A notable feature of the Ahom reign in Assam was the con. struction of large 'tanks' or open reservoirs of water, of which the surrounding embankment and the level of the water enclosed therein were considerably above the level of the surrounding countryside. Most of these tanks are in existence to-day, one fine specimen near Sibsagar town having a perimeter of more than two miles. The tanks were dug on the site of a spring, the position of the spring within the tank being indicated by a substantial post, and it is said to have been the custom of the Ahoms to bury an earthenware vessel of mercury at the foot of the post and on the site of the spring in the belief that the water would thereby be purified and the tank remain clean and free from undesirable vegetable growths.

We are not aware of any documental evidence for these statements, but they are so well founded in the folk-lore of the people that there seems little reason for doubting at least a substantial basis of truth.

$$
\begin{gathered}
\text { Tocklai, } \\
\text { Cinnamara P.O., }
\end{gathered}
$$$$
\text { Assam. }
$$$$
\text { W. WIGHT. }
$$$$
\text { P. K. Barua. }
$$

\section{Ninhydrine Reaction in the Quantitative Determina-} tion of Different Amino Acids

IN the so-called ninhydrine reaction there is formed, in addition to carbon dioxide, an aldehyde corresponding to the particular amino-acid present. When the reaction is carried out so that the formation of aldehyde is as quantitative as possible, the amino-acid can be determined by the aldehyde. We have made this method quantitative for $\alpha$-alanine, which gives acetaldehyde ${ }^{1}$. The ninhydrine reaction can also be applied to the quantitative determination of certain other amino-acids. Thus one of us (Laine) has developed the method for the determination of leucine by means of isovaleraldehyde formed in the reaction ${ }^{2}$. We are continuing our work for the determination of other amino acids in the same manner.

The ninhydrine reaction for the determination of the total amino nitrogen has also been improved by

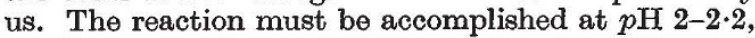
as the ammonium sulphate employed as the condensing substance forms colour with ninhydrine already at $p \mathrm{H} 2 \cdot 5$ and above that.

Artturi I. Virtanen.

T. LAINE.

Biochemical Institute,

Helsinki.

Sept. 8.

${ }^{1}$ Skand. Archiv Physiol., in the Press.

'Suomen Kemistilehti, B, in the Press.

\section{Energy Levels of the ${ }^{24} \mathrm{Mg}$ Nucleus}

Using the cloud chamber method, we ${ }^{1}$ have investigated the beta-ray spectra of ${ }^{24} \mathrm{Na}$. The K.-U. plot showed clearly the existence of two groups. The energy difference between the higher energy group and the lower one is about $1 \mathrm{Mv}$., their relative intensities being 2,3 and 1 respectively. The higher energy group lies on the first forbidden Sargent curve, for which $\Delta i=1$, while the lower one is on the permitted Sargent curve, $\Delta i=0$.

Kurie and Richardson ${ }^{2}$ and Richardson ${ }^{3}$ have investigated the gamma-rays emitted by ${ }^{24} \mathrm{Na}$, their results being as follows:

$$
\begin{aligned}
& \begin{array}{llll}
\text { Energy (Mv.) } & \text {.. } & 1.01
\end{array} \\
& 2.04 \quad 3.00 \pm 0.05
\end{aligned}
$$

We have tried to construct an energy-level scheme of ${ }^{24} \mathrm{Mg}$ which accounts for all the above experimental facts regarding the beta- and gamma-rays. For this purpose we made, besides the energy relations, some plausible assumptions as follows :

(1) In the first place, ${ }^{24} \mathrm{Na}$ is assumed to be in a single energy state because it has only one decay constant, and this nucleus emits two beta-ray groups 